\title{
Profitability and Working Capital Management Nexus: Evidence from Food \& Personal Care Products Sector Firms Listed on Pakistan Stock Exchange
}

\author{
DR. MUMTAZ HUSSAIN SHAH \\ Assistant Professor, Institute of Management Studies \\ University of Peshawar \\ FAYYAZ KHAN \\ Postgraduate Scholar, Institute of Management Studies \\ University of Peshawar
}

\begin{abstract}
Working capital management (WCM) usually have an essential role to play in a firm's overall performance, especially those of manufacturing sector. The key aim of the current research work is to find the empirical association amid profitability and working capital management of the Food \& Personal Care Product sector Pakistani firms. Eight companies are selected randomly as a sample from the firms listed on Pakistan Stock Exchange. Secondary data for six years, that is, 2010 - 2016 is gathered from the financial reports of these companies and evaluated through Pearson correlation coefficient and regression analysis techniques, using STATA software. The results prove that Return on Assets (ROA) is negatively correlated with Average Collection Period $(A C P)$ and positively correlated with Inventory Turnover in Days (ITID), Average Payment Period (APP), Current Ratio (CR) and Sales Growth (SG). All the relationships are significant except ITID and $S G$ ones.
\end{abstract}

Keywords: Working Capital, Profitability, Food \& Personal Care Products, ROA, ACP, $A P P, I T I D, C R, S G, K S E$.

\section{Introduction}

Prudent working capital management (WCM) of a firm is considered among the key influential aspects of gauging its financial condition. It summarizes the liquidity status of a firm as it comprises of the balance sheet short term components. Hence, it is the basic source of a firm's internal financial management assessment (Eljelly, 2004). It represents the current assets which help to improve the financial resources that changes during daily operations of a firm from one type into another type of items (Gitman, Juchau, \& Flanagan, 2015). WCM efficiency is important for manufacturing sector companies because significant portion of assets is constituted of short term assets (Van Horne \& Wachowicz, 2008). WCM directly influences profitability as well as liquidity of corporations (Raheman \& Nasr, 2007). It is imperative to give consideration to WCM and to trade-off between profitability and liquidity or else a firm may face financial failure or bankruptcy (Kargar \& Blumenthal, 1994; Shah \& Khan, 2017).

Furthermore, working capital management is especially significant for sectors such as food and personal care products' because the major part of their assets is in current shape. Therefore, it calls for researcher's attention as previously this sector is inadequately explored. Current assets contain the cash equivalent, inventories, marketable securities, cash receivables, prepaid expenses and other current assets. Deducting current liabilities from current assets gives net working capital. Decisions effecting working capital are 
collectively referred to as working capital management. Firms maintaining appropriate levels of current assets and current liabilities easily meet their short term obligations and can guarantee uninterrupted daily operations. On the contrary lax WCM management leads to negative net working capital indicating deficit in working capital.

WCM can improve the performance of a firm. Its objective is to maintain balance in day to day operations in order to maximize profit and minimize liquidity risk. Firm's daily operations may be effected negatively when there is shortage of working capital. Excess of working capital will increase opportunity cost especially in organizations using external financial sources for working capital. Therefore working capital should be kept at the optimal level in a business. It's obvious that the major goal of an organization is to increase its profits. Raheman \& Nasr, (2007) stated that delaying payments to suppliers is useful for the firm but sometimes they are costly if the supplier offers discount on timely payments.

Hence, WCM plays a vital role in an organization's performance. This study is conducted to get thorough insight and grasp in depth understanding of the correlation between WCM and profitability of Pakistani Food \& Personal Care Product firms.

\subsection{Research Question}

Does a significant relationship exist between profitability and prudent WCM of Food \& Personal Care Product Pakistani firms?

\subsection{Research Gap}

The study focuses on the Food \& Personal Care Product sector companies listed at Pakistan Stock Exchange (PSE) with the aim of finding out the nexus between WCM and profitability. To our knowledge, no such study is performed on this sector prior to our work.

\subsection{Significance of the Study}

WCM influences the profitability as well as liquidity of a firm. Previous empirical works concluded that WCM globally affects the profitability of companies. However, the Food \& Personal Care Products (FPCP) is so far not explored. This study will be the first effort to gauge the WCM possible influence on the profitability of FPCP firms listed on PSE.

\subsection{Scope of the Study}

For this research, 8 firms out of the total 20 firms listed on PSE are selected as a sample from Food and Personal Care Product sector. The data is collected for 6 years starting from 2010 to 2016. So, the possible number of observations for each variable is 48 (Shah, 2009).

\subsection{Limitation of the Study}

Due to unavailability of data this study is restrained only to a six years' time period, from 2010 to 2016, consisting of 8 firms from the Food \& Personal Care Product sector listed at Pakistan Stock Exchange. Furthermore, in light of the literature only five most suitable variables are selected (Shah \& Qayyum, 2015).

\subsection{Scheme of the Study}

Introduction is followed by review of the literature, synthesising the previous researchers work on this topic. Third part shows the methodology used for the study, hypothesis created, data collection method, selection and explanation of variables, theoretical framework and statistical model used for the analysis of data. Section four is about analysis of data and interpretation of the derived results. The fifth one concludes the research paper.

\section{Literature Review}

Raheman and Nasr (2007) states that a firm should give adequate attention to working capital management otherwise, they will be unable to maintain the optimum levels of 
liquidity and profitability, leading to possibly bankruptcy. Smith (1973) proved that numerous organizational failures are due to manager's incompetence to properly allocate and effectively control current assets and current liabilities ratio. Smith (1980) further added that WCM is vital since it shapes a firm's profitability and ultimately its stock value.Working capital has to be suitably planned and controlled because it deals with two important segments of balance sheet i-e current liabilities and current assets (Raheman, Qayyum \& Afza, 2011). In order to avoid bankruptcy an organization needs to keep enough liquid assets to meet its short term liabilities. For assessment of WCM efficiency, cash conversion cycle (CCC) is considered the basic tool (Richards \& Laughlin, 1980). Firms maintaining liquidity through excessive short term borrowings, face trade-off between earned profits and interest payable to creditors. Extremely high or very low level of liquidity has its associated costs (Yeager \& Seitz, 1989). In contrast to traditional belief, Blinder and Maccini (1991) believes that firms investing more in working capital increase their profitability. For example, maintaining high inventory reduce chances of production process pause, minimize price fluctuation risks, avoid stock out losses and also reduce supply shock associated costs.

Deloof (2003) probed WCM's impact on 1009 Belgian firms' profitability for 1992 to 1996. Results show that profitability is inversely related to CCC, receivable time, inventory turnover and payable period. The author suggested that reducing receivable collection period and inventory turnover will possibly lead to efficient WCM. Afza and Nazir (2007) evaluated conservative and aggressive WCM policies for 205 Karachi Stock Exchange listed companies during 1998-2005. They concluded that aggressive policy of managing WC has negative impact on firm's profits. Ganesan (2007) researched efficiency of WCM for 349 Telecommunication \& equipment industry firms for 20012007. He shows that effective WCM do not effects financial performance and profitability has a strong negative relation with industry's liquidity.

Chawla, Harkawat and Khairnar (2010) studying WCM, liquidity and profitability relationship of three petrochemical Indian firms for 2004-2009, through linear regression analysis and Pearson correlation, proves that there is significant inverse relationship between company's profitability with $\mathrm{CCC}$ and its components, that is, receivable collection period, inventory turnover and creditors settlement period; whilst, a statistically significant negative relationship exists between firm's profitability and liquidity. Gill, Biger and Mathur (2010) considered profitability and WCM association of 88 New York Stock Exchange listed companies for 2005-2007. Using gross profit as dependent variable regression analysis showed CCC's positive and account receivables period's negative relationship with firm's profitability. Nobanee, Abdullatif and AlHajjar (2010) investigated firm's CCC effect on profitability of 34771 small, middle and large sized Japanese firms for the years 1990-2004. The results show a strong inverse relation of account receivables and cash conversion cycle with profitability, except for services sector and consumer good enterprises. They suggested that managers should adopt possible ways of reducing $\mathrm{CCC}$, accounts receivables and extend short term payment time to suppliers.

Ali (2011) studies the connection between WCM and the firm's profitability by analysing 160 textile sector companies from 2000-2005, through fixed effect panel technique. The results reveal that average receivable and average payable time is negatively related to inventory turnover and return on assets; CCC is positively related to ROA. Bieniasz and Gołaś (2011) worked on WCM impact on Poland's and other Eurozone economies food industry profitability from 2005 to 2009 . Using CCC, accounts receivables, inventory turnover, current liabilities, turnover cycles and return on assets their findings show that 
minimizing CCC result in increased rate of profitability for the food industry. It means that profitability is negatively affected by accounts receivables, inventory turnover in days and positively by current liabilities. Saghir, Hashmi, and Hussain (2011) studied the significance of WCM for profitability. Using ANOVA and Pearson correlation for 60 KSE listed textile sector firms from 2001-2006 it is found that profitability is negatively affected by both the account receivables and account payables in days.

Kulkanya (2012) tested WCM impact on profitability of 255 Thailand Stock Exchange listed corporations for 3 years from 2007 to 2009. The findings suggest that decreasing the time span of inventory conversion, receivable collection and CCC, leads to increased profitability. Muhammad, Ullah and Jan (2012) studied profitability and WCM relationship for Pakistani textile firms from 2001-2006. Their findings show that profitability has a strong direct association with cash, inventory and account receivables and exhibits an inverse relationship with accounts payable. Ngwenya (2012) studied profitability-WCM nexus for 69 Johannesburg Stock Exchange listed firms from 19982008. Pearson correlation and regression analysis showed significant positive relationship of accounts payable and significant negative rapport of CCC with profitability. Pouraghajan and Emamgholipourarchi (2012) empirically analysed WCM effect on market evaluation and profitability of Tehran Stock Exchange listed companies from 2006 to 2010. Using return on invested capital and ROA ratios as proxies for profitability, Tobin-Q measuring firms' market value, against current ratio, CCC, total debt to total asset ratio, quick ratio and current liabilities to total assets ratio; a significant positive relation between profitability and effective WCM was found. They suggest that minimizing CCC and total debt to total asset ratio, helps the management to improve a firm's profitability.

Sarbapriya (2012) assessed profitability and WCM rapport for 311 Indian manufacturing firms during 1996-1997 and 2009-2010. His analysis of ACP, APP, CCC, ITID, current ratio, debt ratio and company's size reflects strong inverse relation between these measures of WCM and corporate profitability. Usama (2012) extending the work of Raheman and Nasr (2007) analysed 18 KSE listed food sector firms to examine WCM and profitability association for 2006-2010. Regressions analysis showed a significant positive effect of WCM on liquidity and profitability. According to results, firm's size and financial asset to total asset ratio affect profitability positively while ACP influence it negatively. Vural, Sökmen and Çetenak (2012) examined WCM impact on profitability of 75 Istanbul Stock Exchange listed firms for 2002-2009. They observed inverse relation of CCC, debt ratio and receivable collection period with profitability. Regression analysis showed that Tobin-Q has a positive relation with CCC and an inverse one with debt ratio. Firm's size positively influences profitability.

Thuraisingam (2013) probed WCM effects on profitability for 47 firms listed at Colombo stock exchange from 2008-2011. Correlation and regression analysis showed direct significant association between profitability and working capital management. Zubair and Muhammad (2013) empirically studied WCM influence on corporate profitability for 21 KSE listed cement industry companies from 2004 to 2010. They found a negative WCMfirm's profitability connection. Agha (2014) studied the WCM-profitability relationship for Glaxo Smith Kline form 1996 to 2011. The results show that profitability is not affected by current ratio while working capital proxies such as average inventory turnover, average collection and payment period significantly influences it.

Similarly, Iqbal and Zhuquan (2015) empirically studied WCM-profitability link for 85 KSE listed companies from 2008 to 2013. They concluded that ACP, ITID, APP and CCC have inverse relationship with ROA used as a profitability measure. While firm size 
and sales growth positively influences ROA meaning that bigger enterprises have higher return on assets as compared to small companies and growing sales usually lead to higher profitability. Muhammad, Jibril, Wambai, Ibrahim and Ahmad (2015) examined the WCM effect on profitability of 7 food product firms listed on Nigerian Stock Exchange for 2008-2012. Using descriptive statistics and regression analysis, they found that current ratio; firm's size and ACP showed positive relationship with profitability while ITID and APP showed negative relationship with profitability of food product firms. They suggested that high liquidity is costly for the firm. The firms should invest more in working capital to generate profit. Shah and Khan (2017) analysed the profitability of 14 Pakistani commercial banks for eight years from 2007-2014. Using pooled regression analysis it was found that equity to assets, debts to assets, deposits to assets, bank size and assets management have a significant influence on the commercial banks profitability in Pakistan.

\section{Research Methodology}

This section presents the hypothesis, the conceptual framework derived from the past literature, methods and model used for testing and analysing WCM effect on firm's profitability of Food \& Personal Care Product firms listed at Pakistan Stock Exchange.

\subsection{Hypotheses}

Based on the past literature and theoretical knowledge of the subject, following hypothesis are set to answer the research question of the study.

$\mathrm{H}_{0}=$ No relationship exists between WCM and profitability of Food \& Personal Care Product firms in Pakistan.

$\mathrm{H}_{1}=$ A significant relationship exists between WCM and profitability of Food \& Personal Care Product firms in Pakistan.

\subsection{Regression model}

For the purpose of testing the above hypothesis the following regression model is used:

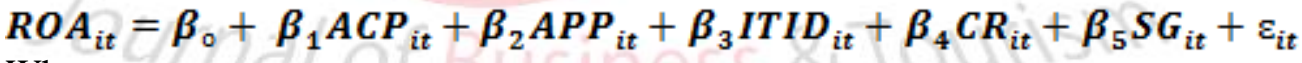
Where,

ROA means Return on Assets. ACP is Average Collection Period. ITID is Inventory Turnover in Days. APP means Average Payment Period. CR represents Current Ratio. $\mathrm{SG}$ is used for Sales Growth and $\varepsilon$ is the error term. All of them are discussed below one by one.

\subsection{Sample Size}

Data for the variables included in the study is collected from the annual reports of 8 out of 20 Food \& Personal Care Product companies listed at PSE for a time period of six years, that is, from 2010 to 2016. Firms' selection is subject to data availability (Shah, 2014).

\subsection{Dependent or Criterion Variable \\ 3.4.1 Return on Assets (ROA)}

Return on assets measures the profitability of a firm with respect to its assets. It shows how efficiently a firm utilizes its assets. ROA is the variable most commonly used by previous researchers. It is obtained through dividing the net income by total assets of an organization.

$$
\text { Return on Assets }=\frac{\text { Net Income }}{\text { Total Assets }}
$$




\subsection{Independent or Predictor Variables}

\subsubsection{Average Collection Period (ACP)}

It is important for measurement of working capital efficiency. It is the average time for collecting the short term receivables from debtors. It can be expressed as:

\subsubsection{Average Payment Period (APP)}

$$
\text { ACP }=\frac{\text { Account Receivables }}{\text { Sales }} \times 365
$$

This indicates the average time for paying the debts to the creditors. Usually, this time period is more than the previous one. It is expressed as:

\subsubsection{Inventory Turnover in Days (ITID)}

$$
A P P=\frac{\text { Account Payable }}{\text { Sales }} \times 365
$$

It shows how much time is required for the inventory to be converted into cash or account receivables. It is very useful for assessment of inventory management. In order to obtain ITID, divide the inventory on cost of sold goods and multiply it by 365 .

\subsection{Control Variables}

$$
I T I D=\frac{\text { Inventory }}{\text { Cost of Goods Sold }} \times 365
$$

\subsubsection{Current Ratio (CR)}

Current ratio is selected as control variable because it has an important relationship with profitability of firms as it shows their liquidity position. It indicates the organization's capability to pay its short term liabilities from current assets. It is calculated as given below.

\subsubsection{Sales Growth (SG)}

$$
\text { CR }=\frac{\text { Current Assets }}{\text { Current Liabilities }}
$$

Sales growth shows yearly growth of firm sales. It is obtained by subtracting last year sales from the sales of current year and then dividing it by previous year sales.

$$
S G=\frac{\text { Sales of Current Year }- \text { Sales of Previous Year }}{\text { Sales of Previous Year }}
$$

\subsection{Conceptual Framework}

Figure one gives the conceptual framework summarising the relationship between the dependent and all the independent and control variables (Shah \& Afridi, 2015).

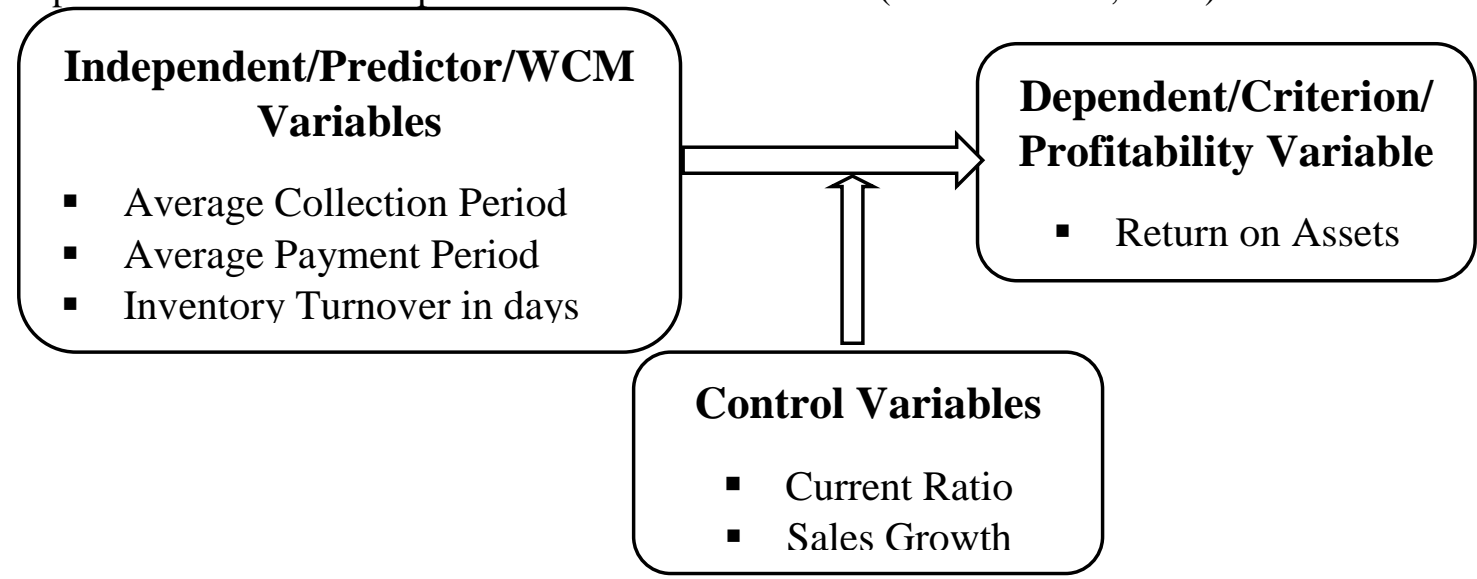

Figure 1: Conceptual Framework 


\section{Data Analysis and Results}

Initially we discuss the data and its related issues followed by results and analysis.

\subsection{Descriptive Statistics}

Descriptive statistics provides us with the summary of the basic information about the variables (Shah, 2011a). It shows the mean values, standard deviation, maximum, minimum values of the data and total number of observations (Shah \& Samdani, 2015).

Table-1 provides descriptive statistics for the eight Food \& Personal Care Products' firms included in the sample for the period of six years from 2010 to 2016. It is visible from the table that receivables, on average, take 14.38 days to be collected with the SD of 13.35 days. The lowest value of ACP is 0.40 days while the maximum value is 57.77 days which means that the quickest payer pays in less than a day whereas from the slowest it can take up to 58 days to collect receivables. The mean value of APP is 61.85 days with SD of 43.42 days. Industry's lowest value for paying short term debts is 15.33 days while it took 213 days on maximum to pay short term debt to suppliers. Normally, the longer a firm waits to pay short term bills, the higher will be profitability of firm. Moreover, industry took 81.42 days on average to convert inventory into sales with standard deviation of 42.59 days. Minimum value for inventory turnover is 12 days and the maximum is 168.67 days.

Table 1: Descriptive Statistics

\begin{tabular}{cccccc}
\hline Variables & Mean & Std. Dev & Minimum & Maximum & No. of Observations \\
\hline ROA & 10.7000 & 10.06728 & -10.01 & 29.84 & 48 \\
ACP & 14.3846 & 13.35611 & 0.40 & 57.77 & 48 \\
APP & 61.8590 & 43.42894 & 15.33 & 213 & 48 \\
ITID & 81.4254 & 42.59195 & 12 & 168.67 & 48 \\
CR & 1.4479 & 0.61032 & 0.67 & 3.04 & 48 \\
SG & 16.3238 & 13.45891 & -25.03 & 44.64 & 48
\end{tabular}

The liquidity indictor i-e current ratio (CR) has a mean of 1.44 and SD is 0.61 . Although, higher CR is good for a firm's liquidity but it also indicates that firm has surplus current assets which may be costly if remains unused. Furthermore, sales growth (SG) of the industry on average is $16.32 \%$ with the standard deviation of $13.45 \%$. The industry is growing rapidly.

\subsection{Correlation Analysis}

Correlation analysis, specifically Pearson correlation, shows the interconnectivity amid the variables (Shah, 2015). Therefore, it is used for the purpose of testing the correlation between working capital and profitability (Shah, 2011c). Table 2 shows the correlation between all the variables included in the analysis. We found that average collection period (ACP) with a value of -0.105 has negative relation with return on assets (ROA). Firms with shorter ACP are likely to be more profitable. The average payment period (APP) shows significant direct relation with return on assets and the correlation coefficient is 0.240 . It reveals that firms are more profitable with longer account payable period. 
Table 2: Pearson Correlations Matrix

\begin{tabular}{ccccccc}
\hline Variables & ROA & ACP & APP & ITID & CR & SG \\
\hline ROA & 1.000 & & & & & \\
ACP & -0.105 & 1.000 & & & & \\
APP & 0.240 & 0.317 & 1.000 & & & \\
ITID & 0.097 & 0.442 & -0.017 & 1.000 & & \\
CR & 0.192 & 0.420 & -0.037 & 0.346 & 1.000 & \\
SG & 0.192 & -0.295 & -0.208 & 0.046 & 0.010 & 1.000 \\
\hline
\end{tabular}

ITID has a direct relationship with ROA having the correlation coefficient of 0.097. This positive relation between ITID and ROA can be explained by virtue of the fact that firms holding excess level of inventory can overcome the cost of supplying goods. They don't face scarcity of merchandises, are protected from adverse future price fluctuations and the firms' production process runs smoothly without interruptions (Blinder \& Maccini, 1991). Current ratio (CR) shows a direct relationship with ROA meaning that an increase in CR increases profitability. Its correlation coefficient is 0.192 .

Sales growth (SG), and ROA also exhibits a positive rapport with a correlation coefficient of 0.192 . This means an increase in SG enhances the profitability of firms and vice versa. The correlations between the variables educate us about the extent of the relationship between them (Shah \& Ali, 2016). However, excess linearity between the independent variables can lead to the multicollinearity problem during the regression analysis (Shah, 2011b). Therefore, to check for its existence we have to carry our certain diagnostic tests.

\subsection{Variance Inflation Factor}

Variance Inflation Factor (VIF) is used to measure the degree of collinearity between independent variables in regression analysis (Shah, 2017d). Correlation greater than 90\% between predictors can lead to multicollinearity issue (Shah, 2011f). Multicollinearity can be a problem as it may cause high variance of regression coefficients which results in difficulty to interpret it and the findings may not reflect the true picture (Shah, 2016a). Table 3 shows the multicollinearity existing between the variables selected.

Table 3: Variance Inflation Factor

\begin{tabular}{ccc}
\hline Variable & VIF & 1/VIF \\
\hline ACP & 1.82 & 0.548898 \\
ITID & 1.36 & 0.733720 \\
CR & 1.32 & 0.760279 \\
APP & 1.19 & 0.839433 \\
SG & 1.17 & 0.857340 \\
Mean VIF & & 1.37 \\
\hline
\end{tabular}

According to the above table, VIF of all variables are below the bench mark minimal multicollinearity of 5\% or above (Shah \& Khan, 2016). Therefore it is expected that the regression analysis is reflecting un biased true results.

\subsection{Regression analysis}

To further examine the causality relationship between WCM and profitability, multiple linear regression analysis is done for all the variables used in the study. Table 4 shows the regression analysis carried out by using the following regression model:

$$
R O A_{i t}=\beta_{0}+\beta_{1} A C P_{i t}+\beta_{2} A P P_{i t}+\beta_{3} I T I D_{i t}+\beta_{4} C R_{i t}+\beta_{5} S G_{i t}+\varepsilon_{i t}
$$

The results in table four supports the findings of the Pearson Correlation Coefficients discussed earlier. The strong, negatively significant, coefficient of average collection 
period manifests that; shorter the collection time, higher will be the profitability of the firm.

Table 4: Regression Results

\begin{tabular}{|c|c|c|c|c|c|c|}
\hline \multicolumn{4}{|c|}{ Number of Observations $=48$} & & R-squared & $=0.2452$ \\
\hline $\mathrm{F}(5,42)$ & $=2.7$ & & & & \multicolumn{2}{|c|}{ Adj R-squared $=0.1553$} \\
\hline \multicolumn{4}{|c|}{ Probability $>\mathrm{F}=0.0319$} & & Root MSE & $=9.2526$ \\
\hline ROA & Coefficient & Std. Error & $\mathrm{t}$ & $\mathrm{P}>|\mathrm{t}|$ & \multicolumn{2}{|c|}{ [95\% Conf. Interval] } \\
\hline (Constant) & -3.404 & 4.829 & -0.705 & 0.485 & -0.5734936 & -0.0229906 \\
\hline $\mathrm{ACP}$ & -0.298 & 0.136 & -2.187 & 0.034 & 0.0268818 & 0.163785 \\
\hline APP & 0.095 & 0.0 & 2.811 & 0.007 & -0.0362155 & 0.1130958 \\
\hline ITID & 0.038 & 0.037 & 1.039 & 0.305 & 0.0837499 & 10.32003 \\
\hline CR & 5.202 & 2.5 & 2.051 & 0.047 & -0.106168 & 0.3309503 \\
\hline SG & 0.112 & 0.108 & 1.038 & 0.305 & -13.1485 & 6.341123 \\
\hline
\end{tabular}

On the contrary Average Payable Period (APP) exhibit a positive significant coefficient indicating that firms are more profitable if they delay the payment to their suppliers and vice versa. Liquidity measured through current ratio (CR), has a significant positive coefficient, clearly showing that increase in CR will affect the ROA positively. In other words firms in Food \& Personal Care Product may increase the profitability if they hold more current assets with respect to current liabilities.

Inventory Turnover in Days (ITID) and Sales Growth (SG), though, has positive coefficients but both fail to reach conventional significant levels. Therefore, their effect is immaterial. The overall explanatory power of the model as indicated by $\mathrm{R}$ squared is $24.52 \%$, implying that the model or all the explanatory variables collectively explains a quarter of the variation in firms' profitability.

\section{Conclusion and Recommendations}

Working capital is an important factor for an organization because it enhances organisation performance in terms of profitability. Gross working capital is total short term assets of an organisation, while net-working capital is excluding the short term assets from short term liabilities. The difference between current liabilities and current assets also shows a firm's liquidity. The basic motive of the research was to explore the WCM and profitability Nexus in the Pakistani Food \& Personal Care Product companies. Results of 8 firms for 6 years show that there is significant relationship between WCM and profitability.

Average Collection Period has significant negative relation with Return on Assets. In other words, firms can increase profitability by minimizing collection period. The faster they collect cash, higher will be profitability. On the other hand, Average Payable Period and Current Ratio has significant positive relation with profitability. This indicates that delaying payment to suppliers and creditors improves the performance of the firm with the fact that firm has the cash for longer period and can utilize it for their needs. Furthermore, it is obvious that food sector need high current assets because it is the major part of their business, so the positivity in relation of CR with profitability is consistent with the fact that firms are more secure with the high liquidity ratio and protected from possible bankruptcy.

Contrary to earlier research and despite theoretical justification Inventory Turnover in Days and Sales Growth has insignificant positive relation with Return on Assets. This is alarming because stock of inventory can help continuity of production and smooth 
running of the business without any interruption. Firms are protected from the future rise and fall of prices. Similarly following the phenomena of economy of scale, sales growth should have exerted a strong significant positive influence. However, this is not the case. The last two findings require the attention of contemporary researches working on WCM and firm's profitability. Based on data availability a longer time span and larger number of firms can lead to new insights on the subject and clears some muddy waters. Similarly, micro firm level data on aspects currently not studied will also produce innovative conclusions and set nouvelle dimensions to the phenomenon examined.

\section{References}

Afza, T., \& Nazir, M. S. (2007). Is it better to be aggressive or conservative in managing working capital? Journal of Quality and Technology Management, 3(2), 11-21.

Agha, H. (2014). Impact of working capital management on profitability. European Scientific Journal, 10(1), 374-381.

Ali, S. (2011). Working capital management and the profitability of the manufacturing sector: A case study of pakistan's textile industry. The Lahore Journal of Economics, 16(2), 141-178.

Bieniasz, A., \& Gołaś, Z. (2011). The influence of working capital management on the food industry enterprises profitability. Contemporary Economics, 5(4), 68-81.

Blinder, A. S., \& Maccini, L. J. (1991). The resurgence of inventory research: What have we learned? Journal of Economic Survey, 5(4), 291-328.

Chawla , P., Harkawat, S., \& Khairnar, I. (2010). Working capital management and profitability - Case of Indian Petrochemicals Company-Ril, HPCLl, Cail. International Journal of Research in Commerce and Management, 1(6), 90-95.

Deloof, M. (2003). Does working capital management affect profitability of Belgian firms? Journal of Business, Finance and Accounting, 30(3-4), 573-588.

Eljelly, A. M. (2004). Liquidity-profitability tradeoff: An emperical investigation in an emerging market. International Journal of Commerce and Management, 14(2), 48-61.

Ganesan, V. (2007). An analysis of working capital management efficiency in telecommunication equipment industry. Rivier academic journal, 3(2), 1-10.

Gill, A., Biger, N., \& Mathur, N. (2010). The relationship between working capital management and profitability: Evidence from the United States. Business and Economics Journal, 10(1), 1-9.

Gitman, L. J., Juchau, R., \& Flanagan, J. (2015). Principles of managerial finance. Pearson Higher Education AU.

Iqbal, A., \& Zhuquan, W. (2015). Working capital management and profitability evidence from firms listed on Karachi Stock Exchange. International Journal of Business and Management, 10(2), 231-235.

Kargar, J., \& Blumenthal, R. A. (1994). Leverage impact on working capital in small businesses. TMA journal, 14(6), 46-46.

Kulkanya, N. (2012). Effects of working capital management on the profitability of Thai listed firms. International Journal of Trade, Economics and Finance, 3(3), 227232.

Muhammad, M., Ullah, K., \& Jan, W. U. (2012). Working capital management and profitability: An analysis of firms of Textile Industry of Pakistan. Journal of Managerial Sciences, 6(2), 155-165.

Muhammad, S., Jibril, R. S., K/Wambai, U. S., Ibrahim, F. B., \& Ahmad, T. H. (2015). The effect of working capital management on corporate profitability: Evidence 
from Nigerian Food Product Firms. Applied Finance and Accounting, 1(2), 5563.

Ngwenya, S. (2012). The relationship between working capital management and profitability of companies listed on the Johannesburg Stock Exchange. Journal of Modern Accounting and Auditing, 8(8), 1204-1213.

Nobanee, H., Abdullatif, M., \& AlHajjar, M. (2011). Cash conversion cycle and firm's performance of Japanese firms. Asian Review of Accounting, 19(2), 147-156.

Pouraghajan, A., \& Emamgholipourarchi, M. (2012). Impact of working capital management on profitability and market evaluation: Evidence from Tehran Stock Exchange. International Journal of Business and Social Science, 3(10), 311-318.

Raheman, A., \& Nasr, M. (2007). Working capital management and profitabaility: Case of Pakistani frims. International Review of business research papers, 3(1), 279300.

Raheman, A., Qayyum, A., \& Afza, T. (2011). Sector-wise performance of working capital management measures and profitability using ratio analysis. Interdisciplinary Journal of Contemporary Research in Business, 3(8), 285-303.

Richards, V. D., \& Laughlin, E. J. (1980). A cash conversion cycle approach to liquidity analysis. Financial Management, 9, 32-38.

Saghir, A., Hashmi, F. M., \& Hussain, M. N. (2011). Working capital management and profitability: Evidence from Pakistan. Journal of Contemporary Research in Business, 3, 1092-1105.

Sarbapriya, R. (2012). Evaluating the impact of working capital management components on corporate profitability: Evidence from Indian Manufacturing Firms. International Journal of Economics Practices and Theories, 2(3), 2247-7225.

Shah, M. H. (2009). FDI induced growth in developing countries: Does human capital matter? PhD Conference. $5^{\text {th }} \& 11^{\text {th }}$ March, 2009. Economics Department, University of Leicester, Leicester, UK.

Shah, M. H. (2011a). Bilateral linkages with OECD and FDI inflows in leading developing countries. International Journal of Interdisciplinary Social Sciences, $5(7), 255-270$.

Shah, M. H. (2011b). Essays on foreign direct investment in developing countries (Doctoral dissertation, University of Leicester).

Shah, M. H. (2011c). The effect of associations with OECD economies on FDI inflows in leading/emerging developing countries. $4^{\text {th }}$ Italian Doctoral Workshop in Economics and Policy Analysis. 7-8 July, 2011. University of Torino and Collegio Carlo Alberto, Via Real Collegio 30, 10024 Moncalieri, Torino, Italy.

Shah, M. H. (2011d). Networking with OECD economies, enhancing inward FDI in emerging developing countries. $7^{\text {th }}$ UK Social Networks Conference. 7-9 July, 2011. University of Greenwich, Greenwich Campus, Old Royal Naval College, London, UK.

Shah, M. H. (2011e). World Trade Organisation and inward foreign direct investment in developing countries: Is it TRIMS, TRIPS or Liberalisation? $6^{\text {th }}$ International Conference on Interdisciplinary Social Sciences. 11-13 July, 2011. University of New Orleans, 2045 Lakeshore Drive, CERM 245, New Orleans, LA 70122, USA.

Shah, M. H. (2011f). The significance of infrastructure for inward FDI in developing countries. International Conference on Applied Business \& Economics, ICABE, 2011. $29^{\text {th }}$ September to $1^{\text {st }}$ October, 2011. University of Applied Sciences, Metropolitan Hotel, 385 Syngrou Ave, 17564, Athens, Greece. 
Shah, M. H. (2012). The significance of infrastructure for FDI inflow in developing countries. Challenges for Analysis of the Business and the Economy-Scientific Conference. 13-16 September, 2012. University of Applied Sciences, Bahnhofstrasse, 15745 Wildau, Berlin, Germany.

Shah, M. H. (2013a). The importance of adherence to intellectual property rights (IPRs) treaties/ conventions for FDI inflows in emerging economies: evidence from OECD outward FDI. European Economics and Finance Society, EEFS2013, The Twelfth Annual EEFS Conference. 20-23 June, 2013. Westin Grand, Berlin, Germany.

Shah, M. H. (2013b). The effect of macroeconomic stability on inward FDI in developing countries. European Economics and Finance Society, EEFS2013, The Twelfth Annual EEFS Conference. 20-23 June, 2013. Westin Grand, Berlin, Germany.

Shah, M. H. (2014). The role of human capital in the host economy on inward FDI in developing countries. West East Institute, European Academic Conference Budapest, WEI 2014, 22-25 June, 2014. Mercure Budapest Korona, Hungary. Organized by West East Institute, 19382 West Chester, PA, USA.

Shah, M. H. (2015). Impact of trade liberalization on FDI inflows in emerging countries. International Social Sciences and Education Research Conference ICBTS2015, 9-13 June, 2015. Harvard University, Boston, Massachusetts, USA.

Shah, M. H., \& Afridi, A.G. (2015). Significance of good governance for FDI inflows in SAARC countries. Business \& Economic Review. 7(2), 31-52.

Shah, M. H., \& Faiz, M. (2015). Terrorism and foreign direct investment: An empirical analysis of SAARC countries. City University Research Journal, 5(2), 219-233.

Shah, M. H., \& Qayyum, S. (2015). Impact of double taxation treaties on inward FDI in Latin American and Caribbean developing countries. Business \& Economic Review. 7(1), 1-18.

Shah, M. H., \& Samdani, S. (2015). Impact of trade liberalization on FDI inflows to D-8 countries. Global Management Journal for Academic \& Corporate Studies, 5(1), 30-37.

Shah, M. H. (2016a). The effect of intellectual property rights on foreign direct investment in East Asia and Pacific developing countries. European Economics and Finance Society, EEFS2016, The fifteenth Annual EEFS Conference. 16-19 June, 2016. Crown Plaza Hotel, Amsterdam, Netherland.

Shah, M. H. (2016b). Financial development and foreign direct investment: The case of Middle East and North African (MENA) developing nations. University of Haripur Journal of Management, 1(2), 93-109.

Shah, M. H. (2016c). The effect of macroeconomic stability on inward FDI in African developing countries. International Journal of Business Studies Review. 1(1), 111.

Shah, M. H., \& Ali, Z. (2016). What drives foreign direct investment to BRICS? PUTAJ Humanities and Social Sciences, 23(1), 51-66.

Shah, M. H., \& Khan, Y. (2016). Trade liberalization and FDI inflows in emerging economies. Business \& Economic Review, 8(1), 35-52.

Shah, M. H., (2017a). Significance of WTO's trade related investment measures (TRIMS) agreement for inward FDI in Sub-Saharan Africa. City University Research Journal, 7(1), 17-29.

Shah, M. H., (2017b). Political institutions and the incidence of FDI in South Asia. Business \& Economic Review, 9(1), 21-42. 
Shah, M. H., (2017c). Inward FDI in East Asian \& Pacific developing countries due to WTO led liberalisation. Business \& Economic Review, 9(2), 1-20.

Shah, M. H., (2017d). Economic institutions \& FDI in South Asia. $6^{\text {th }}$ International Institute of Social \& Economic Sciences, Business \& Management Conference, 27-30 June, 2017. Novotel, Geneva, Switzerland.

Shah, M. H., \& Khan, A. U. (2017). Factors determining capital structure of Pakistani non-financial firms. International Journal of Business Studies Review. 2(1), 4659.

Shah, M. H., \& Khan, S. (2017). Factors effecting commercial banks profitability in Pakistan. Journal of Business and Tourism. 3(1), 1-12.

Smith, K. (1980). Profitability versus liquidity tradeoffs in working capital management. Readings on the Management of Working Capital, 549-562.

Smith, K. V. (1973). State of the art of working capital management. Financial Management, 50-55.

Thuraisingam, R. (2013). The effects of working capital management on company profitability: evidence from Srilankan listed companies. South Asian Academic Research Journals, 3(12).

Usama, M. (2012). Working Capital management and its affect on firm's profitability and liquidity: In other food sector of (KSE) Karachi Stock Exchange. Arabian Journal of Business and Management Review, 1(12), 62-73.

Van Horne, J. C., \& Wachowicz, J. M. (2008). Fundamentals of financial management. Pearson Education..

Vural, G., Sökmen, A. G., \& Çetenak, E. H. (2012). Effects of working capital management on firm's performance: Evidence from Turkey. International Journal of Economics and Financial Issues, 2(4), 488-495.

Yeager, F. C., \& Seitz, N. E. (1989). Financial institution management, text and cases. Englewood Cliffs. NJ: Prentice Hall.

Zubair, A., \& Muhammad, Y. G. (2013). Impact of working capital management on profitability: A case of the Pakistan Cement Industry. Interdisciplinary Journal of Contemporary Research in Business, 5(2). 